\title{
A decade of glacier investigations for utilisation of Greenland hydropower
}

\author{
Anker Weidick and Henrik Højmark Thomsen
}

\begin{abstract}
Over the past decade GGU has collected basic glaciological, climatic and hydrological data from the basins that are potential suppliers of hydropower in West Greenland. Detailed topographic maps of the margins of the Inland Ice near Frederikshåb and Jakobshavn have been used to record changes in the drainage pattern due to changing positions of the ice margin. Landsat images are used to augment the field data, particularly using scenes recorded late in the melting season under low sun angles. Computer processing of the Landsat data enhances individual elements that are otherwise not clearly discernable.

Since ice-dammed lakes can form natural reservoirs they have been closely studied with a view to controlling the periodic catastrophic outbursts.

Statistical modelling has been used extensively utilising long series of meteorological data from coastal stations to simulate the mass balance and runoff patterns on the margin of the Inland Ice.
\end{abstract}

\section{Preconceptions and preliminary investigations}

The potential of Greenland hydropower came into focus following the energy crisis in 1973 and the subsequent demand for exploitation of Greenland's own energy resources. A review of the regional hydrology of West Greenland was prepared in the following years (Weidick \& Olesen, 1980). This took the form of a catalogue of all hydrological basins and their water potential from $60^{\circ}$ to $70^{\circ} \mathrm{N}$. The calculation of the water potential was based on the existing scattered meteorological and glaciological data and on information derived from aerial photographs.

That the glacier cover has a dominating influence on the hydrological condition of Greenland was documented by the figures of this basin report. Of the total discharge from West Greenland (around $220 \mathrm{~km}^{3} /$ year) only $12 \%$ (around $27 \mathrm{~km}^{3} /$ year) could be estimated as deriving directly from precipitation over ice-free land, the rest was precipitation first released from the ice cover as meltwater or calf ice after a period trapped within the glacier system (Table 1). The period it is locked in the glacier system is dependent on glacier size and posi-

Table 1. Origin of potential water as per cent of total amount of water, West Greenland

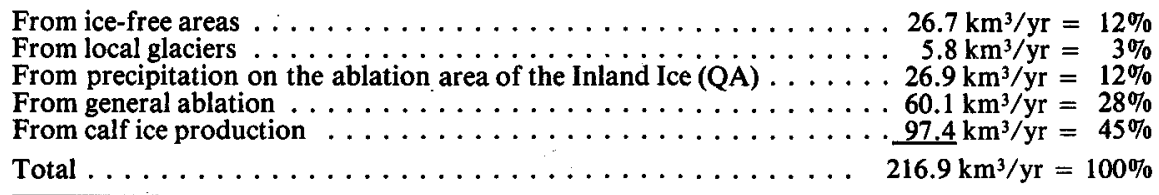


Table 2. Total volumes of water from the West Greenland portion of the Inland Ice

\begin{tabular}{lcccc}
\hline & $\begin{array}{c}\mathrm{QC} \\
\mathrm{km}^{3} / \mathrm{yr}\end{array}$ & $\begin{array}{c}\mathrm{QB} \\
\mathrm{km}^{3} / \mathrm{yr}^{2}\end{array}$ & $\begin{array}{c}\mathrm{QK} \\
\mathrm{km}^{3} / \mathrm{yr}\end{array}$ & $\begin{array}{c}\mathrm{QA} \\
\mathrm{km}^{3} / \mathrm{yr}\end{array}$ \\
\hline Calf ice producing sectors & 120.1 & 22.7 & 97.4 & 7.4 \\
Quiet sectors & 37.5 & 37.5 & 0 & 19.5 \\
Total & 157.6 & 60.2 & 97.4 & 26.9 \\
\hline
\end{tabular}

QC Accumulation over the accumulation area

QB General ablation of the ablation area (melting)

QK Estimated calf ice production

QA Precipitation over the ablation area of the ice sheet

tion, as well as the point of impact of original precipitation above the equilibrium line of the glacier. It may be up to $10^{5}$ years.

Only $6 \mathrm{~km}^{3} /$ year of glacier discharge is meltwater from local glaciers, the rest $\left(184 \mathrm{~km}^{3} /\right.$ year) is calf ice and meltwater from the Inland Ice. Although $128 \mathrm{~km}^{3} /$ year (QB, QK and QA in Table 2) of this amount disappears as meltwater and calf ice from the productive sectors of the ice sheet to the ice fjords, $50-60 \mathrm{~km}^{3} / y$ ear still remains as water from the quieter sectors which have their terminations at higher altitudes. The ice sheet thus has the greatest potential for hydropower exploitation. This is also reflected in the present planning where high priorities are given to localities at the ice margin which could supply future energy for Jakobshavn, Frederikshåb, Christianshåb, and partly also Godthåb/Nuuk.

In many of the coastal basins local glaciers may also have a substantial influence on discharge patterns. This is particularly true for the basins with potential hydropower for Sukkertoppen and Godhavn.

Only a small proportion of the Greenland glaciers have names, but in connection with registration of glacier information all West Greenland's 5000 perennial snow patches, local glaciers and outlets from the Inland Ice are allocated a code which refers to their hydrological system. The same code is the basic address for documentation of glacier characteristics and changes.

\section{Field work}

In the programme set up by GGU it is intended to collect basic glaciological, climatic and hydrological data which can be used either directly or indirectly in planning hydropower projects. The timetable for the programme is shown in fig. 1. At Nordbogletscher, Qamanârssûp sermia and Amitsulôq Iskappe there are fixed stations which are manned from May to September to carry out mass balance measurements, measurements of discharge and ice velocity, and a full programme of climatic observations. The mass balance, or just balance, of a glacier expresses the relationship between gain of material to the glacier (accumulation = e.g. snow deposition) and loss of material (ablation = e.g. melting and calving). Accumulation and ablation is normally measured over a balance year running from the end of one summer to the end of the following summer. The net balance is the balance at the end of the balance year and expresses the algebraic sum of accumulation and ablation, often expressed 


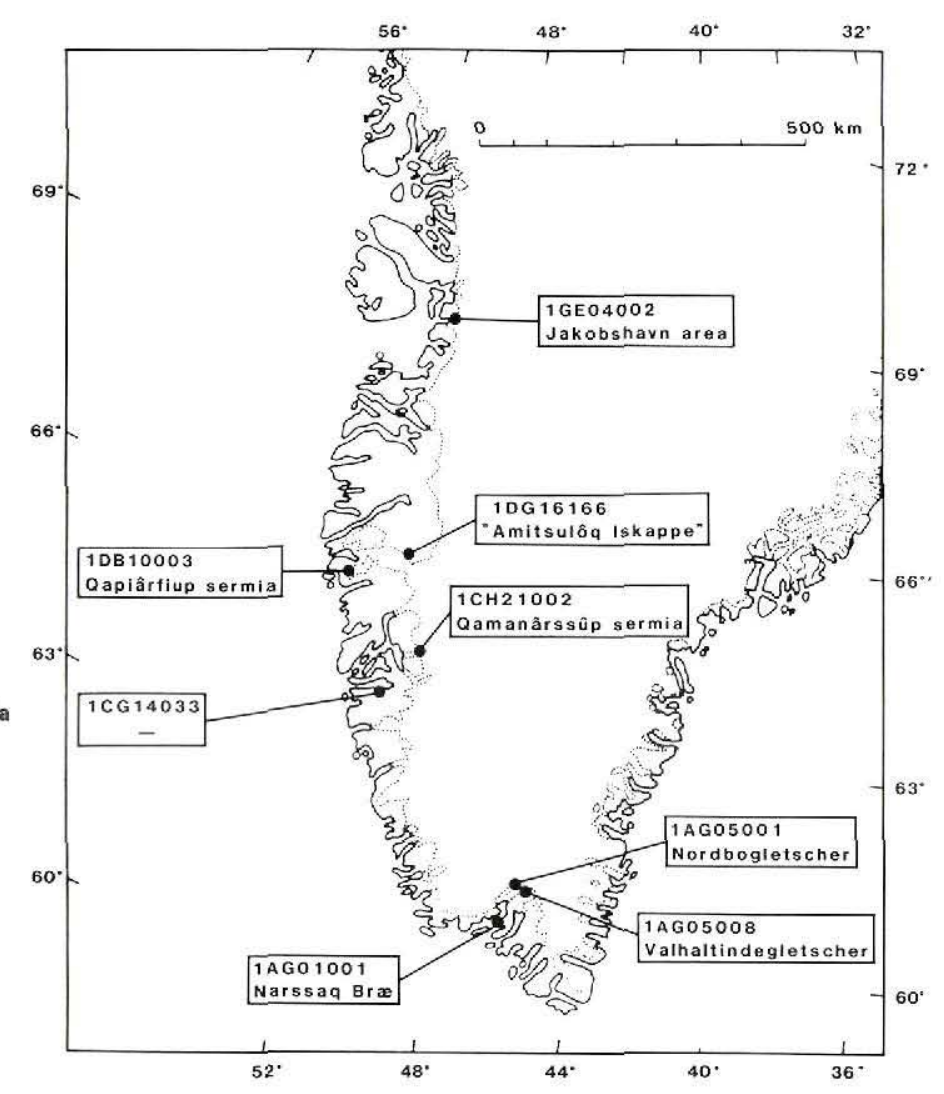

1CH21002
1CG14033 no name
10G16166 "Amitsulôq Iskappe"
10B10003 Qapiârfiup sermia
1GE04002 Inland Ice margin,
Pâkitsup ilordlia
Glaciers, unnamed

Initial phase

[IIIII

Measurements

Planned measurements

1975

1980

1985

1990

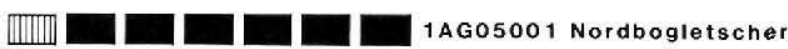

WDW 1AG05008 Valhaltindegletscher

$\square$ 1AG01001 Narssaq Bræ

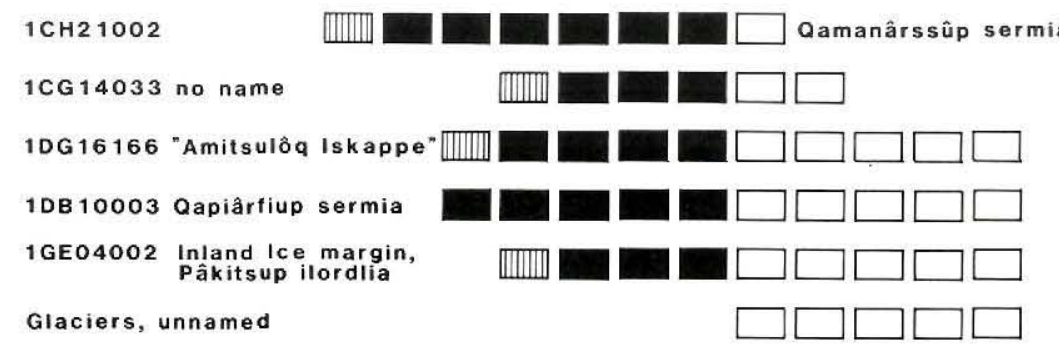

Fig. 1. Location of present and planned investigations of glacier mass balance by the Geological Survey of Greenland (GGU). Glaciers (unnamed) are minor supplementary reconnaissance investigations. Numbers refer to GGU glacier atlas codes (Weidick, in press). 

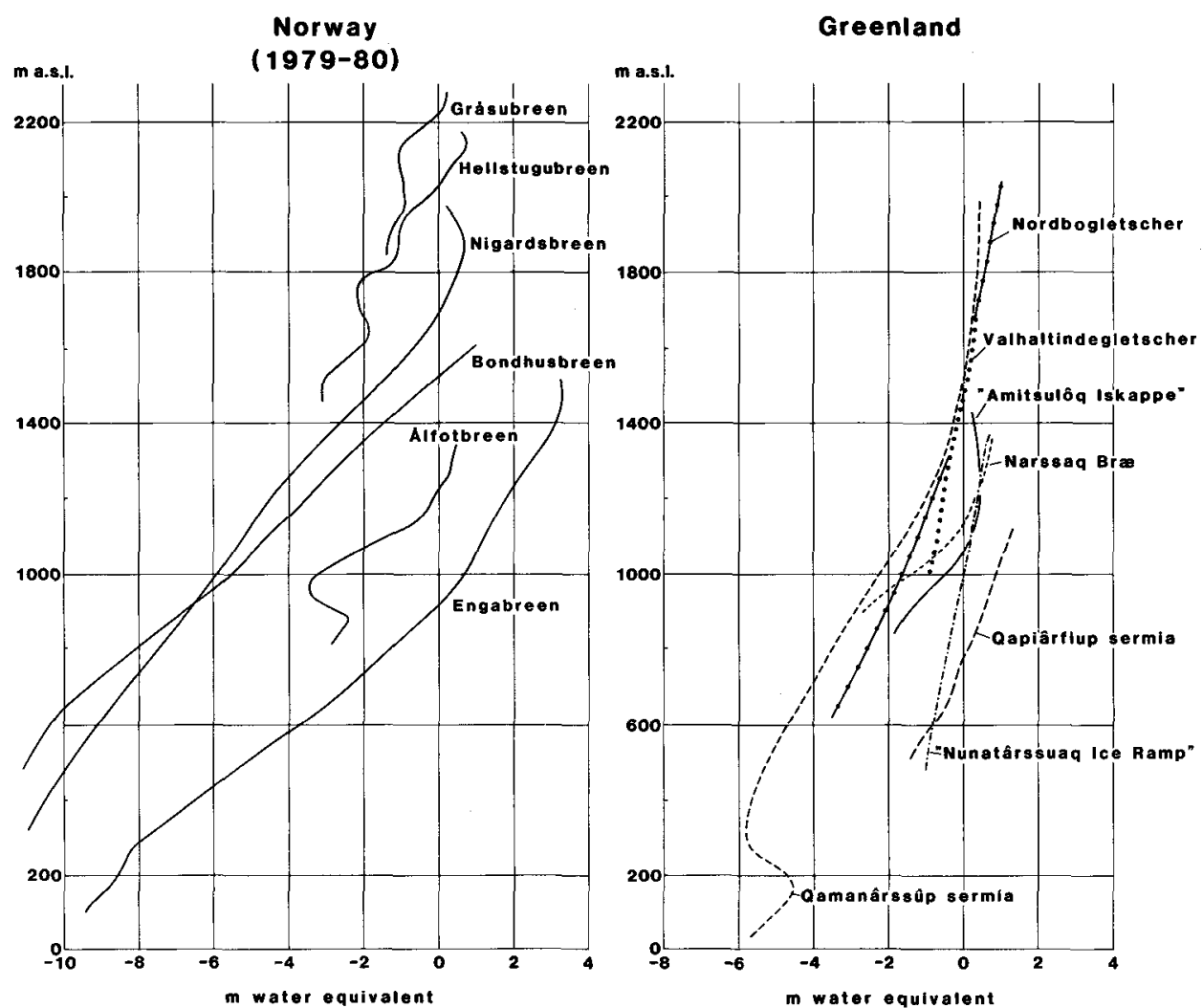

Fig. 2. Mass balance diagrams from West Greenland compared with examples from Norway.

as a function of elevation (fig. 2). Glaciers without fixed observation stations are only visited twice yearly to determine winter and summer balances. Besides the specific use of the mass balance data in selected basins, the geographical spread allows a regional determination of the mass balance patterns for the whole of West Greenland.

Numerous reports have been published from the localities under study (Olesen \& Andreasen, 1983; Clement, 1982, 1983; Braithwaite, 1983; Thomsen, 1984). Some of the results are shown as net balance curves in fig. 2 where they are compared with balance curves from some Norwegian glaciers.

From fig. 2 it can be seen that the activity index (slope of net balance curve at equilibrium line $=$ rate of water transfer in the glacier body) of Greenland glaciers is considerably less than that for Norwegian glaciers. In West Greenland it varies from approximately $2-4 \mathrm{~mm} / \mathrm{m}$ at the Inland Ice margin (e.g. Nordbogletscher) to a maximum of $10 \mathrm{~mm} / \mathrm{m}$ at local glaciers closer to the outer coast (e.g. Narssaq Bræ). Conditions for the melting of the Inland Ice margin are fairly uniform over great distances; the curve for Nordbogletscher $\left(61^{\circ} \mathrm{N}\right)$ is nearly identical with that of Qamanârssûp sermia $\left(64^{\circ} \mathrm{N}\right)$. 


\section{Detailed photogrammetric glacier mapping}

A photogrammetric mapping programme was initiated in response to increasing demand for detailed topographic maps of the areas under investigation. The maps produced have been used as the basis for runoff and glacier dynamic modelling.

Maps at a scale of 1:25000 covering the margin of the Inland Ice north-east of Frederikshåb and Jakobshavn have been produced from vertical aerial photographs (Weidick \& Thomsen, 1983; Thomsen, 1983a). The maps were prepared at the GGU photogrammetric laboratory using a Kern PG-2 stereoplotting instrument connected to a computer system. All possible detail has been plotted for the glacier area and trim line zone. A section of the glacier map north-east of Jakobshavn is shown as fig. 3 .

To determine glacier variations, maps of the glacier surface have from time to time been produced using older vertical aerial photographs and data from recent terrestrial photogrammetric surveys carried out during field work at GGU field stations (Knudsen, 1983). Terrestrial photogrammetric surveys have been carried out at short time intervals along glacier profiles to determine variations in the horizontal ice velocity (Knudsen, 1983).

\section{Mapping of surface and subsurface features on the Inland Ice}

A large proportion of the runoff from the drainage basins proposed for hydroelectric installations is made up of meltwater coming directly from the Inland Ice. The Inland Ice is a relatively unexplored area, and little or no information about detailed surface topography,

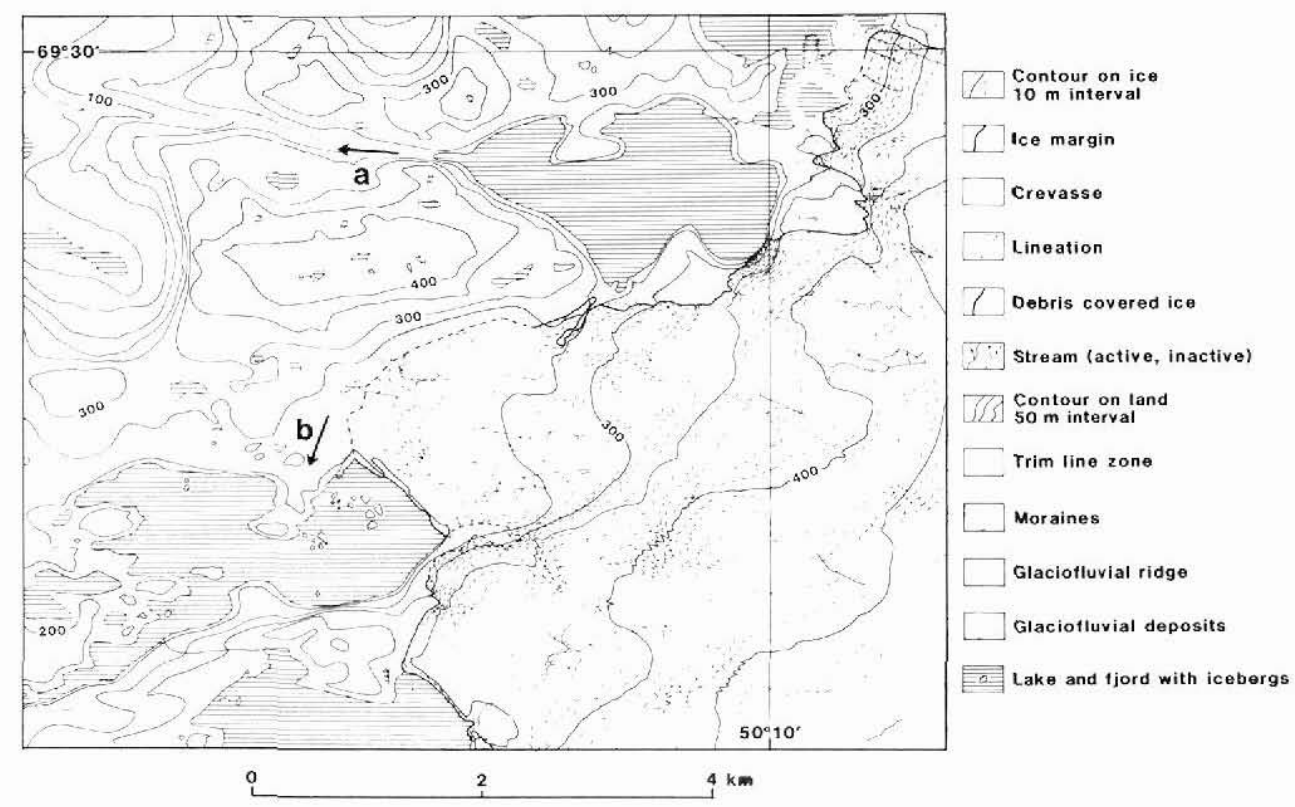

Fig. 3. Section of glacier map north-east of Jakobshavn showing part of the margin of the Inland Ice in 1959. The arrow at 'a' shows former direction of drainage, that at ' $b$ ' the present drainage direction. 


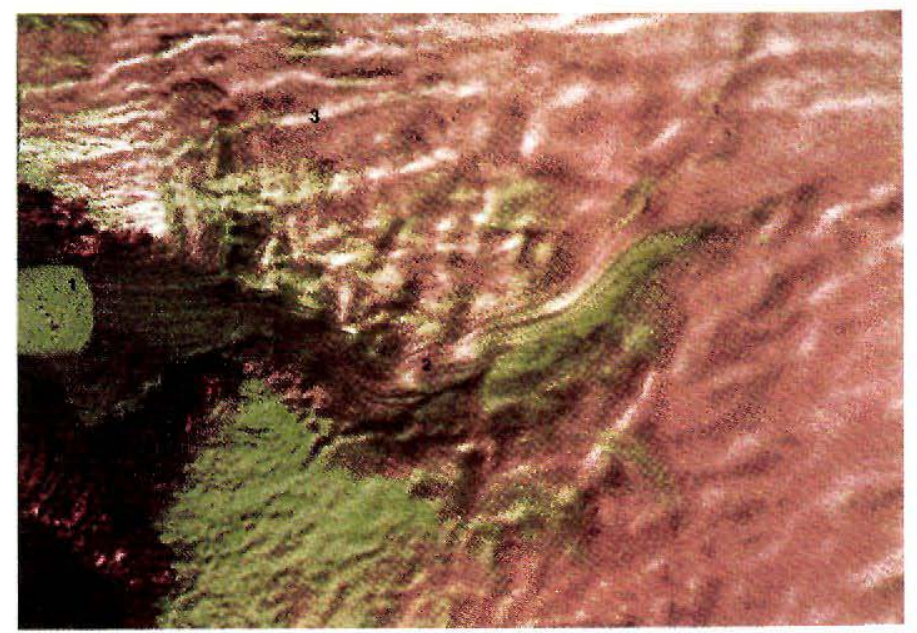

Fig. 4. Jakobshavn Isbre and surrounding sectors of the Inland Ice, east of Jakobshavn. Computer processed part of Landsat 2 scene, acquired 27.09.1979. (1) Glacier margin ending up in fjord, (2) flowlines and (3) shadow patterns from subtle topographic surface features, reflecting the subglacial terrain.

subglacial bedrock topography, meltwater and iceflow pattern is available. There are special problems delineating individual ice streams of the Inland Ice, especially at higher altitudes. There is also the problem that the surface drainage pattern inferred from maps may not reflect the actual englacial and subglacial meltwater drainage. Meltwater may often drain supraglacially through large river systems directly to the glacier margin. However, much of the water reaches the bedrock through crevasses and moulins. The subglacial topography may seriously influence the direction of meltwater drainage either by creating crevasses affecting the surface drainage or by forcing the water to follow subglacial valley systems. Information about subglacial topography is therefore of fundamental importance.

Information from satellites offers several advantages over other methods of glacier observation; for example, a regional view of the Inland Ice becomes possible, and large parts of the ice sheet not covered by aerial photographs can be seen on one frame. In addition satellite data are available from times when aerial photographs are not normally taken.

Data from the Landsat satellite have been used to augment the information on meltwater and iceflow on the Inland Ice and the subglacial topography. Landsat scenes recorded late in the melt season under low sun angles are very suitable, as subtle topographic surface features on glaciers reflecting the subglacial topography are accentuated. Computer processing of the Landsat data can enhance individual elements in the images so that they are more clearly discernable to the eye (Thomsen, 1983c). An example of the possibility of detecting surface features on the Inland Ice by means of Landsat data is given in fig. 4 .

Maps with information on ice and meltwater drainage and the subglacial terrain as depicted from the surface (Thomsen, 1983b) are produced from computer processed Landsat data. Information on melting conditions is given from the different snow facies mapped on the surface of the ice sheet (Thomsen, 1983a).

Drainage basins on the Inland Ice have been delineated from existing topographic maps 


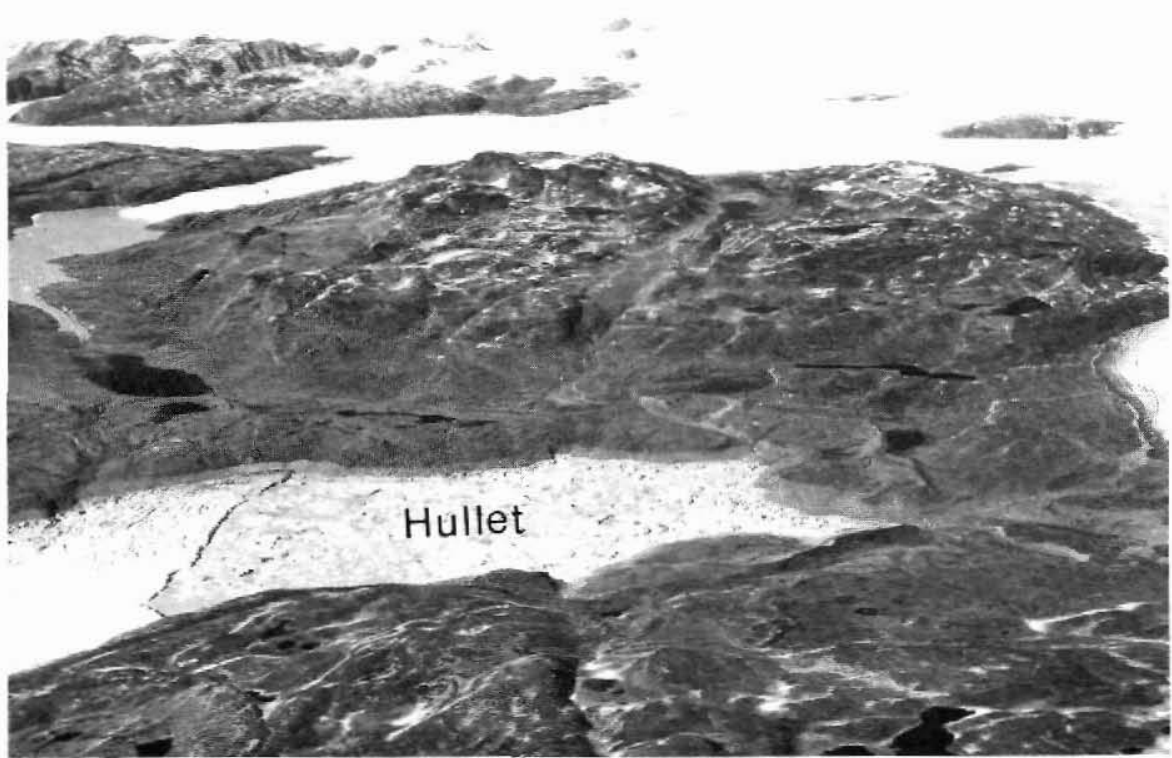

Fig. 5. Aerial photograph of Hullet (route 267 G-N, no. 321, 07.09.1962, courtesy of the Geodetic Institute, Copenhagen). In background the south slope of the Inland Ice with Nordbogletscher.

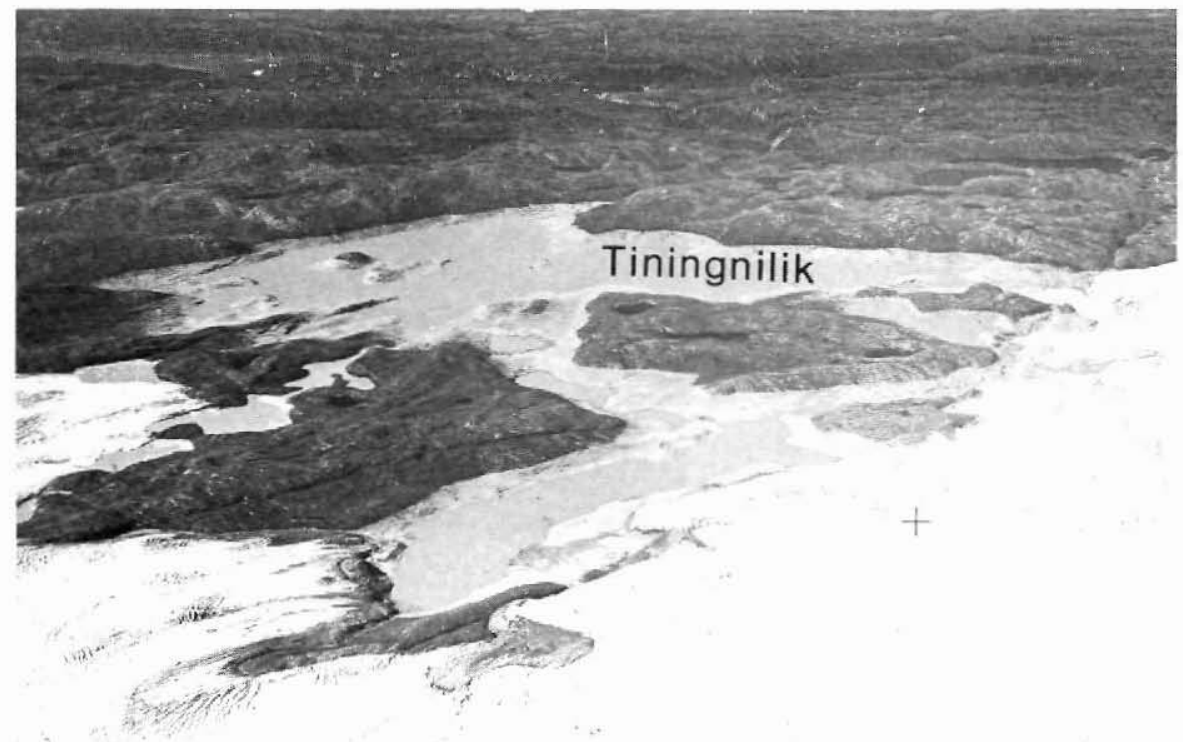

Fig. 6. Aerial photograph of Tiningnilik (route 511 A no. 29, 17.07.1948, courtesy of the Geodetic Institute, Copenhagen). 


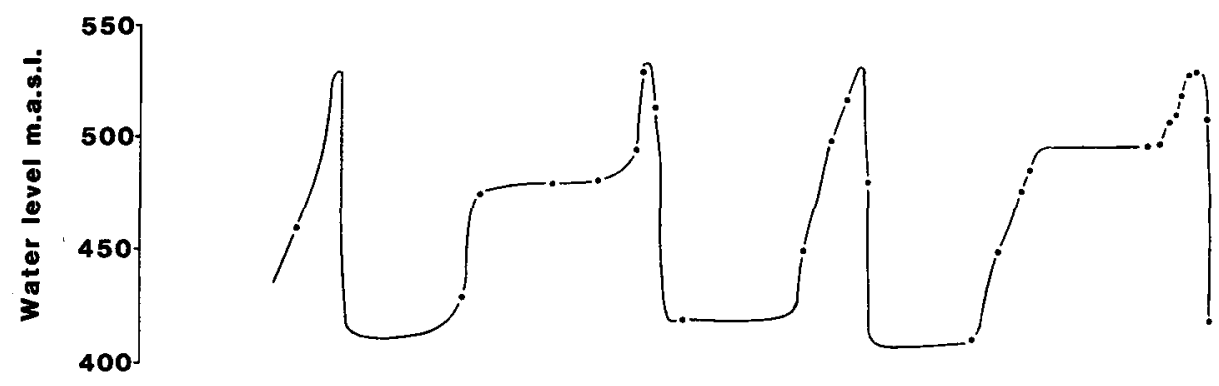

1978

1879

1980

1981

1982

1983

Fig. 7. Water levels and outbursts from the ice-dammed lake Hullet in Johan Dahl Land $\left(61^{\circ} \mathrm{N}\right)$. The irregularities of the saw-tooth curve are due to the uneven infilling of meltwater during the three summer months. Each outburst releases $0.6 \mathrm{~km}^{3}$ of water (Clement, 1983).

and surface feature maps (Thomsen, 1984). Due to the uncertainties involved both maximum and minimum estimates of their extent have been made, differing in the way in which the subglacial terrain is assumed to affect the drainage pattern. For a more exact estimate of the size of the drainage basins, direct measurements of ice thickness are required. For this purpose radio-echo soundings have been attempted as part of the field programme at Nordbogletscher in South Greenland (Clement, 1983) and on the Inland Ice north-east of Jakobshavn, using a $60 \mathrm{MHz}$ and $300 \mathrm{MHz}$ radar developed at the Electromagnetic Institute, Technical University of Denmark. The measurements were carried out on the ice surface using skidoos and from helicopter and fixed-wing aircraft but had limited success up to 1984 due to technical difficulties. The difficulties were overcome the following year and parts of the subsurface of the Jakobshavn ice margin were mapped successfully by $L$. Thorning and $E$. Hansen, GGU.

\section{Observations of ice-dammed lakes}

Along the margin of the glaciers (and especially the Inland Ice) there are a large number of ice-dammed lakes. For hydropower exploitation natural reservoirs in the form of lakes are preferred, as they save construction of expensive dams. Thus ice-dammed lakes directly related to the ice margin have attracted considerable attention.

In the two main schemes, interest has been focussed on large ice-dammed lakes with periodic subglacial outbursts, i.e. lakes slowly filling with meltwater to a critical height (water level) after which the water breaks through the damming glacier subglacially. The lakes are Hullet (fig. 5) in Johan Dahl Land at $61^{\circ} \mathrm{N}$ (Clement, 1984) and Tiningnilik (fig. 6) near Christianshåb at $69^{\circ} \mathrm{N}$ (Braithwaite \& Thomsen, 1984b) which have intervals of 1-2 years and $8-10$ years, respectively, between individual outbursts. The exact interval between outbursts is dependent on the annual ablation, i.e. the rate at which meltwater fills the lakes. The characteristic saw-tooth curve of water level and volume for these lakes is shown in figs $7 \& 8$.

The use of these lakes as reservoirs involves an artificial permanent lowering of the water level to a value below the critical height for outbursts. However, uncertainty still remains 

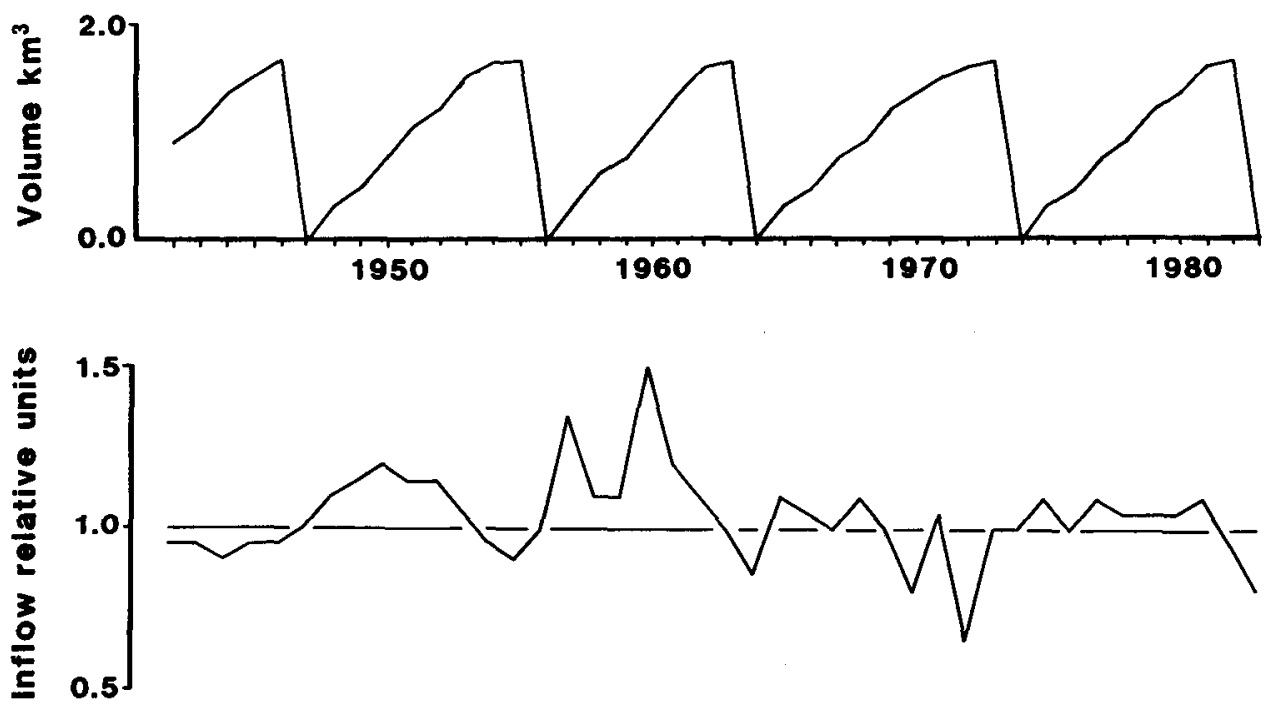

Fig. 8. Calculated variations in volume of the ice-dammed lake Tiningnilik from 1942 to 1983 together with calculated inflow. Outbursts release between 1.5 and $2 \mathrm{~km}^{3}$ of water (Braithwaite \& Thomsen, 1984b).

about details in the mechanism of the outbursts and the effects on the damming glacier body by a permanent lowering of the lake level.

\section{Mass balance and runoff modelling}

Statistical modelling has been used to calculate the mass balance from existing climatic data from the nearest meteorological stations and in this way extending the time coverage of short measured series of mass balance and runoff.

For local glaciers, where the total glacier area can be unambiguously defined from topographical maps, longer mass balance series have been simulated. The simulation is made with the help of an empirical correlation between summer temperature and winter precipitation at the nearest meteorological station and the total mass balance of the glacier measured directly. An example of this procedure is shown in fig. 9 where the mass balance simulation covers the small local glacier, Valhaltindegletscher (Clement, 1983).

Runoff modelling from basins proposed for hydroelectric installations (Braithwaite \& Thomsen, 1984a,b) involves separate treatment of the glacier-covered and the glacier-free areas. Two models are used, MB1 for mass balance and rainfall, and SM1 for snowmelt and rainfall. These models calculate specific values of various water balance elements (e.g. accumulation, ablation and rainfall) as a function of elevation. The total runoff from the basin can then be calculated by integrating the specific runoff values from the MB1 and SB1 models over the appropriate areas. In the first calculation the model only uses climatic data from coastal stations (regional model) and the calculated runoff is then compared with available runoff observations to produce a series of calibrated runoff data (basin-specific model). An example of simulation of this kind is given in fig. 10 . 


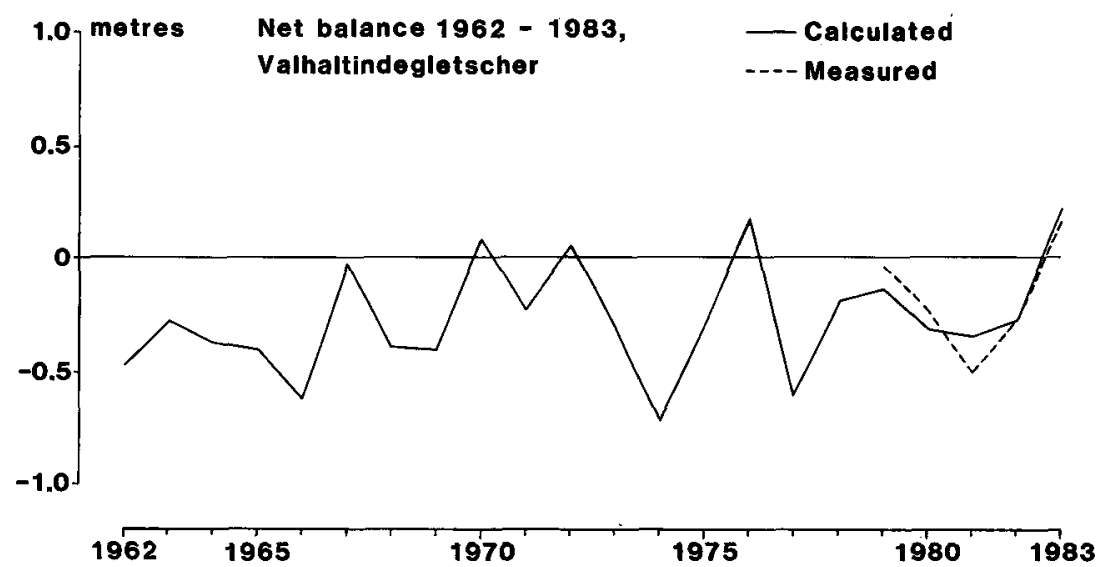

Fig. 9. Calculated net balance on Valhaltindegletscher $\left(61^{\circ} \mathrm{N}\right) 1962-1983$. This local glacier has an area of $1.9 \mathrm{~km}^{2}$. The mass balance has been negative throughout most of the budget years (Clement, 1983).

The calculations suggest that the effect of the ice cover in the basins is to smooth out yearto-year runoff variations compared to a hypothetical ice-free basin. This has an obvious advantage in that it reduces the reservoir capacity required for year to year storage. However, it may be partly offset by the greater seasonal variability in glacier runoff compared to runoff from an ice-free basin.

\section{Registration and modelling of glacier fluctuations}

In connection with the planning of hydropower installations near the ice margin, prognoses of the ice marginal changes are necessary. Recession or advance of the ice margin oc-

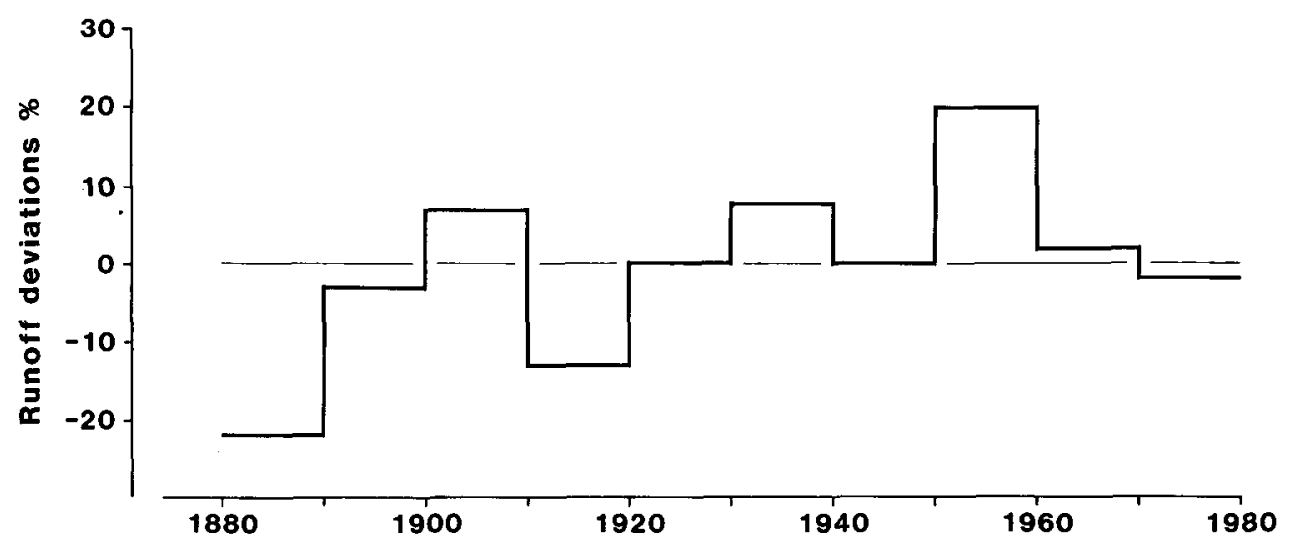

Fig. 10. Calculated variation in runoff over the past century from a sector of the Inland Ice margin at Pâkitsup akuliaruserssua (Jakobshavn area at $69^{\circ} \mathrm{N}$ ). Values are expressed as a percentage of the 19631983 simulated mean annual runoff. The warm spell of the period between the 1920 s and 1960 s can be clearly seen in the curve calculated from the climatic series (Braithwaite \& Thomsen, 1984a). 


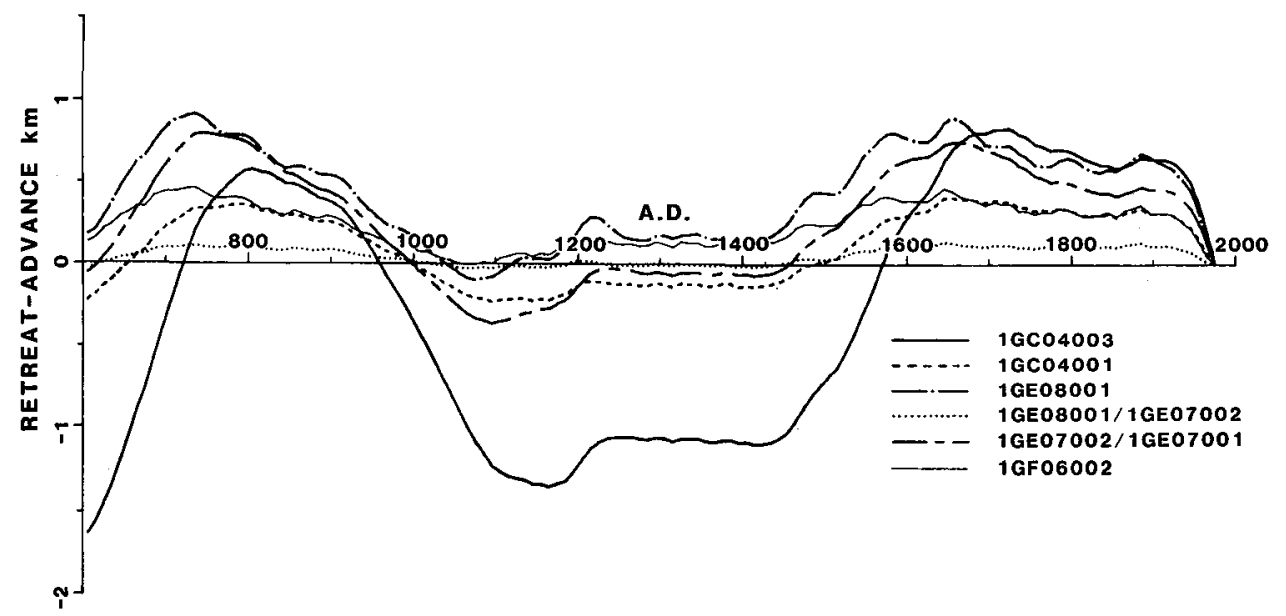

Fig. 11. Advance and retreat of the fronts of six subglaciers (lobes of the Inland Ice) in response to ablation. Fluctuations generated by means of the 2600 year $\left({ }^{18} \mathrm{O}\right)$ series from DYE 3 . Curves cover the time since A.D. 600 and show deviations from the 1975 front positions (Reeh, 1983).

curs commonly with rates up to 10-20 m/year. Exceptional cases with advances up to several kilometres per year can be observed during glacier surges, but these occurrences are rare and are not dealt with here. However, even the normal rates of change may cause substantial changes in the terrain and in the courses of the rivers draining the ice margin.

The locality of Pâkitsup ilordlia (Pâkitsup akuliaruserssua) near Jakobshavn is an example of river changes due to a fluctuation of the ice margin. At this site a hydropower plant for Jakobshavn is planned at the margin of the ice sheet. Here, a slight recession of the ice margin caused a radical change of the drainage so that it shifted from the northern to the southern inner branch of Pâkitsup ilordlia fjord (fig. 3), and a prognosis of the behaviour of the ice margin is required (Thomsen, 1983a). The prognosis is based on simulated mass balance conditions in preceding centuries and on information of the surface and bottom of the ice sheet sectors involved up to the equilibrium line. The main response time here is $100-200$ years so that in the coming decades a continuous, slow recession of the ice margin under present or even slightly colder conditions can be expected. The calculations (made by Reeh, 1983) include the behaviour of the ice margin back to A.D. 600 (fig. 11). Where the simulation can be controlled (e.g. by reports of margin changes during the last 100 years) it showed a good fit with the actual observations.

In general the main part of the glaciers in Greenland are still receding as a consequence of the warm spell between the 1920 s and 1960 s, though stabilization or even readvance of minor local glaciers has been reported in recent decades (Gordon, 1981).

Marginal changes of the ice sheet are not so directly dependent on climatic changes as are local glaciers. Thus, the sectors around Johan Dahl Land in South Greenland have advanced continually at least since 1930 . It is presumed that the advance of this part of the southern slope of the ice sheet is a consequence of the general thinning: subglacial thresholds will then change the outward flow so that some sectors will actually receive increasing amounts of ice. 


\section{Concluding remarks}

The glaciological investigations of the preceding decade have essentially been concentrated on acquisition of the elementary basic mass balance data of a few selected glaciers. Compared to international standards each measurement often represents larger unit areas of the glaciers, and accordingly the measured results cannot produce the same detail. However, a great step forward has been achieved by the compilation of these basic measurements, the importance of which reaches far beyond the localities investigated.

The mere existence of the Inland Ice and its present and past role as a climate buffer of the North Atlantic also implies the necessity of a detailed knowledge of the present mass balance parameters. Since the accumulation pattern of the interior of the ice sheet is relatively well known, the recent measurement of some of the losses has contributed a great deal to the insight of the relationship between climate and ablation.

However, although necessary and fundamental, the application of conventional mass balance measurements has severe restrictions where calculation of the ablation of ice sheet sectors is involved. Remote sensing has supplied a great deal of information for delineation of the sectors and for prognosis of positions of the equilibrium line and hence data transfer from one glacier to another. Additional insight into the internal and subglacial meltwater drainage of the glacier is still needed.

Progress in better delineation of the hydrological drainage and prognoses of glacier behaviour depends on better knowledge of the surface and subsurface of the ice sheet sectors.

There is broad agreement that present mass balance measurements are both time consuming and expensive, even with respect to local glaciers, and other methods have to be attempted. So far it has not been possible to avoid conventional mass balance measurements, but supplementary investigations that yield information on glacier changes, which may contribute to the control of more sophisticated mass balance modelling (including ice dynamics), seem to be a realistic tool for future work in Greenland.

Acknowledgements. Thanks to Dr S. Pala, Ontario Centre for Remote Sensing (OCRS), Toronto, Canada, for discussions of digital processing techniques. The Landsat image (fig. 4) was processed at OCRS.

\section{References}

Braithwaite, R. J. 1983: Glaciological investigations at Qamanârssûp sermia, interim report 1982 and appendix Tables. Grønlands geol. Unders., Gletscher-hydrol. Meddr 83/4, $34+15$ pp.

Braithwaite, R. J. \& Thomsen, H. H. 1984a: Runoff conditions at Paakitsup Akuliaruserssua, Jakobshavn, estimated by modelling. Grønlands geol. Unders., Gletscher-hydrol. Meddr 84/3, 22 pp.

Braithwaite, R. J. \& Thomsen, H. H. 1984b: Runoff conditions at Kuusuup Tasia, Christianshåb, estimated by modelling. Grønlands geol. Unders., Gletscher-hydrol. Meddr 84/2, 23 pp.

Clement, P. 1982: Glaciologi på Narssaq Bræ - Massebalancen 1981 og 1982. Grønlands geol. Unders., Gletscher-hydrol. Meddr 82/5, $27 \mathrm{pp}$.

Clement, P. 1983: Glacial-hydrologiske forhold i Nordbosø bassinet, Johan Dahl Land. Grønlands geol. Unders., Gletscher-hydrol. Meddr 83/9, 54 pp.

Clement, P. 1984: Observationer omkring Hullet - en isdæmmet sø i Sydgrønland. Dansk geol. Foren. Ársskr. 1983, 65-71.

Gordon, J. E. 1981: Glacier margin fluctuations during the 19th and 20th centuries in the Ikamiut kangerdluarssuat area, West Greenland. Arct. Alp. Res. 13, 47-62. 
Knudsen, N. T. 1983: Photogrammetric investigations at glaciers in West Greenland. Rapp. Grønlands geol. Unders. 115, 115-117.

Olesen, O. B. \& Andreasen, J. O. 1983: Glaciological, glacier-hydrological and climatological investigations around $66^{\circ} \mathrm{N}$, West Greenland. Rapp. Grønlands geol. Unders. 115, 107-111.

Reeh, N. 1983: Ikke-stationær beregningsmodel for Indlandsisens randzone, Grønlands geol. Unders., Gletscher-hydrol. Meddr 83/7, 81 pp.

Thomsen, H. H. 1983a: Glaciologiske undersøgelser ved Pâkitsup ilordlia 1982. Ilulissat/Jakobshavn. Grønlands geol. Unders., Gletscher-hydrol. Meddr 83/3, 24 pp.

Thomsen, H. H. 1983b: Satellitdata - et redskab til studier af Indlandsisens randzone i forbindelse med vandkraftundersøgelser. Grønlands geol. Unders., Gletscher-hydrol. Meddr 83/8, 24 pp.

Thomsen, H. H. 1983c: Glaciological applications of Landsat images in connection with hydropower investigations in West Greenland. Proc. EARSel/ESA Symp. Remote Sensing Applications for Environmental Studies. Spec. Publ. Europ. Space Agency 188, 133-136.

Thomsen, H. H. 1984: Glaciologiske undersøgelser i Disko Bugt området 1983. Grønlands geol. Unders., Gletscher-hydrol. Meddr 84/1, $31 \mathrm{pp}$.

Weidick, A. in press: Atlas of West Greenland glaciers.

Weidick, A. \& Olesen, O. B. 1980: Hydrological basins in West Greenland. Rapp. Grønlands geol. Unders. 94, $51 \mathrm{pp}$.

Weidick, A. \& Thomsen, H. H. 1983: Glaciologiske undersøgelser. Frederikshåb/Pamiut 1982. Grønlands geol. Unders., Gletscher-hydrol. Meddr 83/6, 46 pp.

Geological Survey of Greenland, $\emptyset$ ster Voldgade 10 , $D K-1350$ Copenkagen $K$, Denmark. 